\title{
BULLETIN
}

OF

\section{The New York State College of Forestry}

Syracuse University

The Planting of Forest Trees by the Public Schools of the State

A Forest Day for the State to Supplement Arbor Day

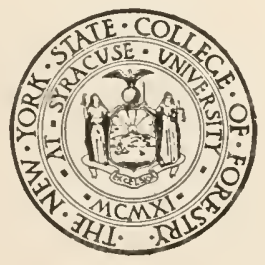

Published Quarterly by the University

Entered at the Postoffice at Syracuse as second class matter 


\title{
PUBLICATIONS OF THE NEW YORK STATE COLLEGE OF FORESTRY
}

\author{
Available upon application for residents of the State
}

The Reforestation of Cut Over and Idle Lands in New York

*Possibilities of Municipal Forestry in New York....By Nelson C. Brown Wood-Using Industries of New York................ Jy John T. Harris The Planting of Forest Trees by the Public Schools of the State

Systematic Street Tree Planting.................. Hy H. Francis Courses in Pulp and Paper Making

Report on the Street Trees of the City of New York

State Forest Camp in the Adirondacks

A Street Tree System for New York City................. By L. D. Cox

\section{TECHNICAL SERIES}

No. 1. 1914. Preliminary Report on the Diseases of Fish in the Adirondacks. A contribution to the Life History of Clinostomum marginatum, by Dr. IV. M. Smallwood, pp. 1-27.

No. 2. I. A New Species of Pityogenes, by J. M. Swaine, pp. 8-10.

I1. Observations on the Life History and Habits of Pityogenes hopkinsi Swaine, by M. W. Blackman, pp. 11-66.

No. 3. 1916. The Development of the Vegetation of New York State, by Dr. William I. Bray, pp. 1-166.

No. 4. 1916. The Relation of the Mollusks to Fish in Oneida Lake, by Frank C. Baker.

\section{LEAFLETS}

Why Forests and Forestry are Necessary in New York.

Hints for the Woodlot Owner.

A Simple Post Treating Plant.

Tree Seeds, Seed Beds and Forest Plantations.

The Economic Side of New York State Woodlands.

The New York State College of Forestry, Its Establishment, Organization and Work, and the Opportunities for lts Graduates.

*Temporarily out of print.

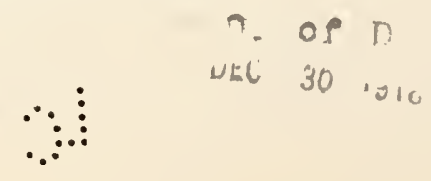




\title{
FACULTY
}

OF

\section{The New York State College of Forestry}

AT

\section{SYRACUSE UNIVERSITY}

\author{
J.MAES Roscoe D.YY, S. T. D., D. C. L., LLD. \\ Chancellor of the Unizersity
}

Hugh Potter Bater, M. F. (Yale 1904); D. Oec. (Munich 1910)

Dean of the College and Professor of Silziculture

Frank F. Mloox, B. A. (Amherst College 1901); M. F. (Yale 1909)

Professor of Forest Engincering

Maulsby Willett Blackian, 1. B. (Lniv. of Kansas 1901); Ph.D. (Harvard Lniv. 1905)

Professor of Forest Entomology

Eid aro F. McCarthy, R. S., M. S. F. (Lniv, of Michigan 1911)

Professor of Forestry at State Ranger School

Neison Colrtinnt Prown, B. A. (Yale College 1906); M. F. (Yale University 1908)

Professor of Furest L'tilization

J. FRED BAKER, B. S. (Michigan Agricultural College 1902): M. F. (Yale University 1905)

Director of Forest Ina'stigations

Leigh H. Pexington, A. L., 1907, Ph.D. (Univ of Michigan 1909)

Professor of Forest Pathology

George ג. Gutches, M. F. (Lniversity of Michigan 1910)

Director of State Ranger. School

John Wallace. Stephen, B. A., M. S. F. (Lniv. of Michigan 1907) ; M. Pd.

(Mich. Normal College 1915)

Assistant Professor of Siliticulture

Retifen Pakker Pricharo, B. S. (Dartmouth College 1907): M. F. (Yale University 1909)

Assistunt Professor of Forest Technology 
Charles Christopher Anams, B. S. (Illinois Wesleyan I896); M. S. (Harvard Univ. I899); Ph.D. (Univ. of Chicago 1908)

Assistant Professor of Forest Zoology

HeNRY R. Fraxicrs, B. S. (Massachusetts Agricultural College 1910) Assistant Professor of Landscape Extension

Harry P. Brown. R. S. 1909, A. M. 1910, Ph.D. (Cornell Ĺniversity 1914) Assistunt Professor of Forest Botany

Sharlity II. Allen, B. S. A. (Iowa State College 1909) Assistant Professor of Forest Errtension

Laurie D. Cox, A. B. (Arcadia College 1903): B. S. L. S. (Harvard (niversity 1908)

Assistant Professor of Landscape Engincering

William A. McDonalin, B. S. F. (Michigan Agricultural College 1913) Assistunt Professor of Forest Lritension

Russela. T.ylor GHEex, B. S. F. (Pennsylvania S'ate College 1912) : M. F. (The New York State College of Forestry 1914)

Assistant Professor of Forest lintension

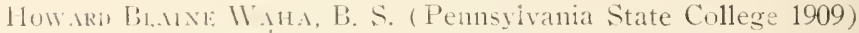

Assistunt Professor of Ficrest Engincering

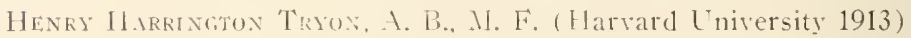
Instructor in Forest L'tiliwation

WilLtaM O. Fulis, A. F. (Lebanon Valley College 1911); M. S. (Iowa State College 1913)

Instructor in Forcst lintomology

CARRTNGTON MICF.IRLANE

Ficld. Assistant in Forest Ina'estigutions

MiLiREn E. Woom, B. L. E. (Syracuse L'niversity 1914)

l.ibrarian

L,ILL,IAN MI. LANG

Secretary to the Dean

WIIFRED L. B.SSETT

Assistant Treasurer

IValter IV. Cimpalan, B. S. ( Wabash College 1893)

Cashier

Martha Jeinette Harington, B. L. E. (Syracuse University 1914, Recorder 


\section{PLANTING OF FOREST TREES BY THE PUBLIC SCHOOLS OF THE STATE}

For a number of years it has been the custom on the first Friday in May of each year for the school children of the Commonwealth to plant one or more shade trees or groups of ornamental shrubs on the grounds surrounding the public schools. Those who introduced this custom believed that the planting of a few trees and shrubs would impress upon the boys and girls of the State the importance of trees in the life of the community, and that constant contact with trees and shrubs which the student had planted with his own hands would create in him a love for nature and for the great out-of-doors.

In many communities Arbor Day has meant much and its observance has resulted not only in a beautification of the school grounds, but in the interesting of many girls and boys in trees and outdoor things generally. The idea of Arbor Day originated in Nebraska, where trees do not grow as easily as in New York and where there have always been fewer trees and therefore a greater need for them. The transfer of Arbor Day bodily from Nebraska to New York has meant that it has not been accepted in many communities because not needed. Many school grounds are already sufficiently planted, and it is to these schools that the College of Forestry appeals especially for the planting of a school forest by the pupils.

The Department of Education of the State of New York has done a great deal in stimulating interest in the celebration of Arbor Day in the past, and it has larger plans for a continuation of an Arbor Day celebration in the schools of the State. There are still many school grounds which need ornamental trees and shrubs, and important lessons may be taught the children through the carrying out of Arbor Day exercises. The New York State College of Forestry at Syracuse University. which was established for the purpose of giving educational work in forestry throughout this State, is in a position to supplement and carry forward the splendid work being carried on by the Department of Education in the observance of Arbor Day. It hopes, therefore, not only to stimulate greater interest 
in Arbor Day by co-operation with the State Education Department, but it proposes to supplement and extend the work begun on Arbor Day by assisting schools in the planting of a thousand or more forest trees so that each school may have a miniature forest of its own. The College is therefore issuing this rather brief announcement with a hope that the high schools especially of the State may become interested in making the planting of trees in the spring something more than a day of exercises and possibly the planting of trees upon grounds already well shaded.

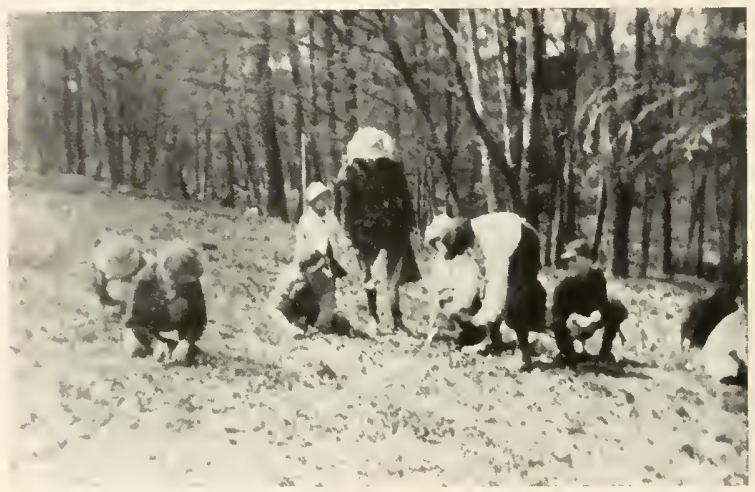

School Children Planting a School Forest under direction of a Forester from Syracuse.

\section{The Idea of a Forest Day to Supplement Arbor Day Developed} Through Need of Protection of the Forests of the State

For several years the College of Forestry has been teaching through the State the necessity for protecting the forests owned by the State in the Adirondacks and Catskills from fire, and, further than this, has been urging the development of a State-ivide forest fire law. It has not met with opposition to these ideas on the part of the people, but it has met constantly with indifference not only from those who own the forests but those who seek the forests for the game they contain or for recreation. As the efforts for forest protection through the State continue it becomes ever more apparent that if permanent results are to follow the educational work done by the College, the children of the State must be taught not only to love the trees but to believe in them as trees and as forests for the ralue which trees and forests have for the State. The Col- 
lege feels that if the boys and girls will take part in the planting of a thousand small trees on some bit of idle land in the vicinity of the school, very much has been done for the protection of the forests of the State. Boys and girls who have planted a miniature forest and watched the trees grow are not going into the forest and leave a burning camp fire or throw down a burning match. Furthermore, they have taken part in a piece of real constructive work for the State and have been introduced in an effective way to the problem of the utilization of the idle lands of the State.

\section{How to Begin a School Forest}

It is not the idea of the College that the starting of a School Forest or the development of a Forest Day in the State shall take the place of Arbor Day or the exercises which have been held through the years upon this Day. The idea of a School Forest for every school in New York is urged by the College as a step beyond what could be successfully carried out in the State before the organization of a strong State College of Forestry to guide the development of this work. The College will co-operate in every possible way with the State Department of Education in its celebration of Arbor Day in the schools and then hopes to guide the next step beyond, which will be the development of a Forest Day, not necessarily coming at the same time as Arbor Day, but at the time best suited to the planting of forest trees.

The idea of planting from one to five thousand trees on some bit of idle land in the vicinity of the school building is generally new to the great mass of pupils in high schools and other public schools, yet some of the schools of the State have been holding a Forest Day for the past three or four years and some schools have already planted from one to ten thousand trees under the direction of Foresters from The State College of Forestry at Syracuse. Two years ago the school children of Hornell set out some 25,000 trees on the city water shed seven miles from Hornell. The peuple of the city were very greatly interested in this Forest Day, took the children from the city to the future forest in motor cars and did all in their power to make the day a success.

The Boys' Conservation League of Glens Falls, New York. made up of a group of school boys, plants each year from one 
to three thousand trees on idle lands both within and withont the city limits. The Leagne developed this idea several years ago and some of the trees planted are now five or six feet in height, giving the boys the pleasure of seeing results of their labors, and they are realizing, therefore, to a surprising extent the part they are playing in real constructive conservation for the State. The school children of Jamestown have actually purchased a School Forest of 100 acres and have already begun some forest work on their "One Hundred Acre Tract."

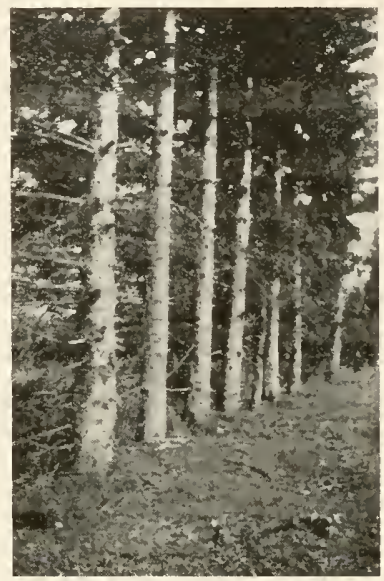

A Sucessful New York Snowbreak.

Last spring eleven different schools of the State took advantage of the service offered by the College and one or more thousand trees were planted by each school. This number included Binghanton High School, Seventh grade boys of Dunkirk Schools, the High School of New Berlin, Pike Seminary in Wyoming county, Newark Valley High School, Owego High School, a country school in Montgomery county, and Sherburne High School.

In nearly all of the work done so far in the State along these lines, the women of the communities interested have been very influential in seeing the work successfully carried out.

\section{Land Suited for Planting Not Difficult to Locate}

With few exceptions, high schools and other public schools interested in beginning a school forest will find pieces of idle land in the form of barren ridges or hillsides in the vicinity of 
the school, the owners of which will be very glad to have planted to forest trees. The nearer the school that these plantations can be located the greater the interest the school will take in the planting. If such pieces cannot be found there are often idle lands about the city reservoirs or in undeveloped portions of city parks. A little inquiry on the part of the instructional force of the school or the boys themselves will bring to light locations where plantings may be done. In some instances it may be possible to find bits of State land so close to the school that they may be secured from the State for School Forest purposes, or permission may be granted by the State for their use by the school.

\section{Securing the Trees and Establishing the Forest}

The State of New York, through its State Conservation Commission leads the States of the Union in the development of forest nurseries and reforestation work. Citizens of New York may secure trees for reforestation work at cost. Stock of sufficient size to plant in school forests ranges in price from $\$ 3.50$ to $\$ 5.00$ per thousand, depending on species and age. The more rapid growing kinds, such as White Pine, Red or Norway Pine and Norway Spruce are recommended for average conditions. Application should be made direct to the State College of Forestry at Syracuse, N. Y.

It is probable that the future forests of the State will be made up of a few rapid growing evergreens and hence the suggestion that the School Forest be planted to these evergreens. We can, as a rule, grow two good evergreen trees to commercial maturity while we are growing one broadleaf or hardwood such as the Ash, Hard Maple or Elm. Should schools prefer to plant hardwoods it will be possible to supply to some extent seedling trees of White Ash, American Basswood or Linden, Whitewood or Tulip, and Red Oak. The hardwoods will be seedlings from one to three years old and the evergreens will be transplants from two to four years old.

Upon the receipt of the trees at the School the box or basket should be opened, and if the planting is to be done within the next day or two, it should be placed in a cool shed or cellar. If it is not possible to do the planting for several days then the trees should be taken out of the basket and the roots buried carefully in fresh soil. If a trench is dug, pre- 
ferably in the shade of a building or on the east or north slope of a hill and the roots placed in the fresh mineral soil in the trench and fresh soil placed back against the roots and tharoughly packed against them, the trees can be kept in good condition in this way for several weeks if necessary. This process is known as "heeling in."

When the planting is to be done the trees can be lifted out of the trench with a spade or mattock, not pulled out, placed in pails with the roots in water or in baskets, with the roots kept covered with moist moss or moist sacks. Three or four good husky boys will plant easily one thousand trees a day.

\section{The State College of Forestry Will Send a Forester for the Supervision of the Planting of the School Forest}

If schools will write to The College of Forestry at Syracuse, suggestions will be given as to the kinds of trees to plant in different soils, where and when to get them and how they may be planted if a Forester is not present to help. The College will be very glad to send out a trained Forester to supervise the planting where the school will plant at least a thousand trees.

The usual way of planting trees is to divide the boys up into groups of 3 or 4 so that one may keep the alignment, one or two dig holes and one do the planting. The usual distance of planting in a school forest is $6 \times 6$ feet. This will call for 1,210 trees to the acre. When planting great care must be taken to remove the duff or sod from the surface, and unless the roots of the little tree are put into the fresh mineral soil and the soil firmly packed around the roots so there will be no air spaces, the little tree is apt to dry out very quickly. A little care used just at the time the roots are put into the ground will mean a great deal in the development of the little tree. Trees grow like weeds in New York and success in planting is largely a question of getting the roots firmly placed in fresh mineral soil at the beginning. With proper planting and ordinary weather conditions, about 90 to 95 per cent. of the little trees should live, and unless the growth of grass and brush is exceedingly heavy where the trees have been planted, it will not be necessary to do anything more than to protect the trees from fire and from being trampled by horses and cattle. 
After the trees have been planted they grow very rapidly and it will be but two or three years before the boys and girls will see the practical results of this constructive work. The necessity for the practice of forestry in New York is no longer a question and the College feels sure that once the boys or girls become interested in a forest plantation they will take the right attitude toward the forests of the State and will understand what Forestry means and what the forests may accomplish for the State, not only in the way of producing lumber but in conserving the water supply of the State and in developing recreation places for the people.

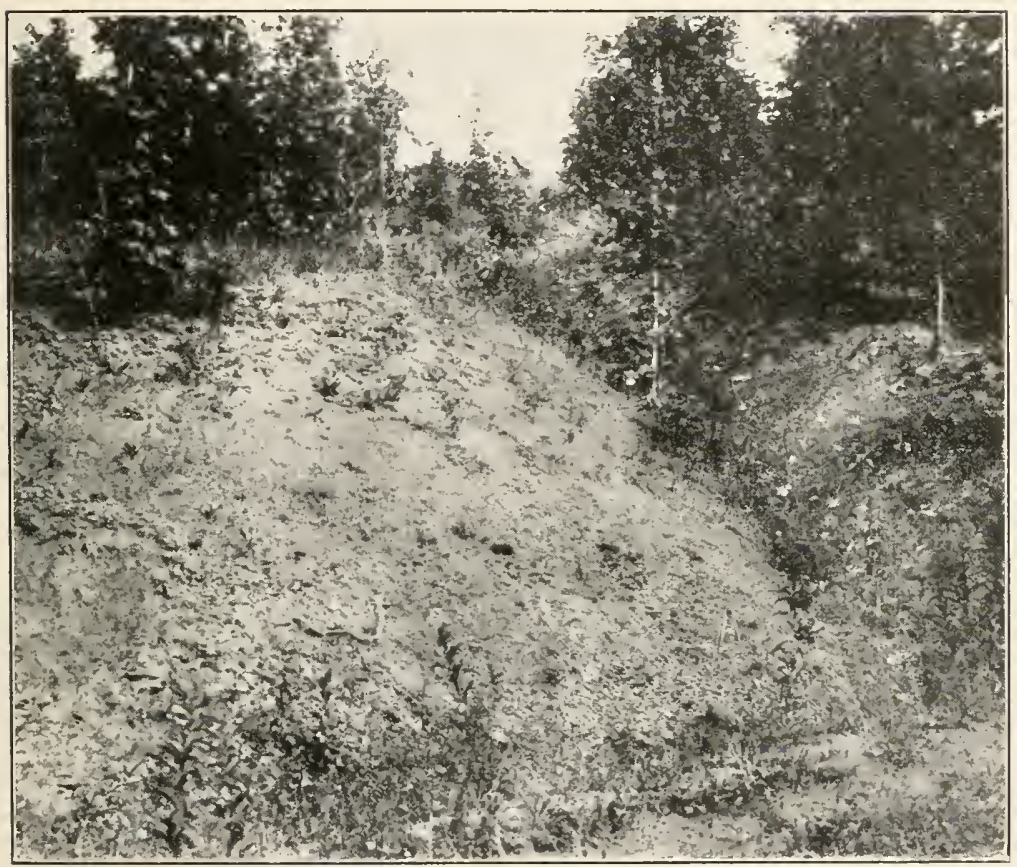

Slope on a New York farm beginning to wash. This should be planted to forest trees.

\section{Plan Early for Forest Day}

It should not be difficult to find some public spirited citizen who will be glad to turn over one to two or three acres of land for the development of a school forest. If this is not possible, take up the matter with the city officials to see if there are not 
sections of undeveloped parks or land about the reservoirs where planting wonld be an advantage from every standpoint.

After securing the land, the College suggests that the principal of the School write, giving accurate description of the soil and moisture conditions of the area. It may be well. where it is difficult to describe the soil, to send a small sample of it by parcel post. The College will then make general suggestions as to the trees suited for the particular school forest. An order sheet will be sent by the College which may be used for ordering the seedlings and this may be filled out and sent directly to the College or to the State Conservation Commission at Albany.

The College will suggest a day for the planting, depending upon weather conditions, and after the day has been settled upon by the school, arrangements will be made for a Forester from the College to guide the students in the planting. It may be desirable to have a talk for the students during the day on Forestry.

The Forester will plan to get to the School the night before or early in the day so as to go over the ground, and will try to meet the older boys so as to organize them into planting groups. It is suggested that the girls assist in the planting either directly through carrying the trees for the planting or in furnishing the lunch for the boys who plant. Before the planting is started the Forester from the College will be glad to give a talk either in the school or in the open on "Trees and what they mean to the community," or will give a more formal illustrated lecture on "Forests and Forestry in New York." The College believes that much can be done in schools in awakening interest in the many phases of the activities of the State through the starting of a School Forest.

\section{Where School Grounds Are Not Fully Planted the College Urges the Observance of Arbor Day by the Planting of Ornamental Trees and Shrubs}

There is nothing that adds, by so small an effort, so much to the attractiveness of the landscape of New York State, as the planting of good, long-lived shade trees. The most pressing needs for the presence of shade trees are along country roadsides, village and city streets, town commons, village greens, city squares, rural cemeteries, recreation areas, play

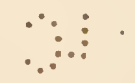


grounds, and school grounds. The New York State College of Forestry will be very glad to assist in helping to lay out school grounds in the city and in the comntry, so that proper provisions maly be made for a good growtl of trees and by recommending the best sorts for special purposes. It is desirable to surround the buildings in which the youth of the State spend a large part of their time, with fine trees, properly planted and cared for. The impression made by beautiful surroundings is as essential to the proper development of our children's training as the providing of comfortable and sanitary buildings and good text books and teachers. School Boards, teachers and children as a rule are glad to improve school grounds if there is someone to suggest how this may be done with reasonable expenditure. Some of the best varieties of shade trees to plant are Norway Maple, Oriental Sycamore, Pin Oak, Red Oak, and Ailanthus for the cities; Anerican Elm. Sugar Maple, Hackberry, White Ash, Red Maple, and Tulip Tree for the towns and villages. The trees recommended for the cities can be best obtained from some nearby commercial nurseries. The varieties for town and conntry use may be secured from the fields and woodlands, although as a general rule, in this case only the small sizes should be transplanted. It is usually possible to interest Village Improvement Socicties. Women's Clubs, and other Civic organizations in giving support to tree planting campaigns. I'here a quantity of sharle trees are to be planted arrangements can sometimes be made to secure free aid from the State through The New York State College of Forestry at Syracuse, N. Y.

\section{Other Helps in Interesting Students in Forests and Their Products}

The State College of Forestry at Syracuse has prepared a set of 30 different hand specimens of woods of the State. These are $3^{\prime \prime} \times 5^{\prime \prime}$ and a little less than $1 / 2$ " thick. Each specimen is carefully labeled and numbered and the label gives the common and technical name of the tree, its distribution and 11se. With the set comes a little pamphlet describing the structure of the wood and making special reference to the set of woods. This set of woods will be furnished to any school or club in the State wishing them at cost, which includes 
transportation. This cost is 50 cents. At all times the College will be glad to identify, at no cost, specimens of trees and shrubs and pieces of wood.

The College is preparing for distribution also a set of some 30 different kinds of tree seeds. These are put up in small glass vials, carefully labeled and will be shipped in a block of wood, each vial in a compartment by itself, so there will be no danger of breakage, and the set will be very easily handled in the school. This set of seeds, with the pamphlet describing them, will be sold at cost which will be the same as for the woods collection.

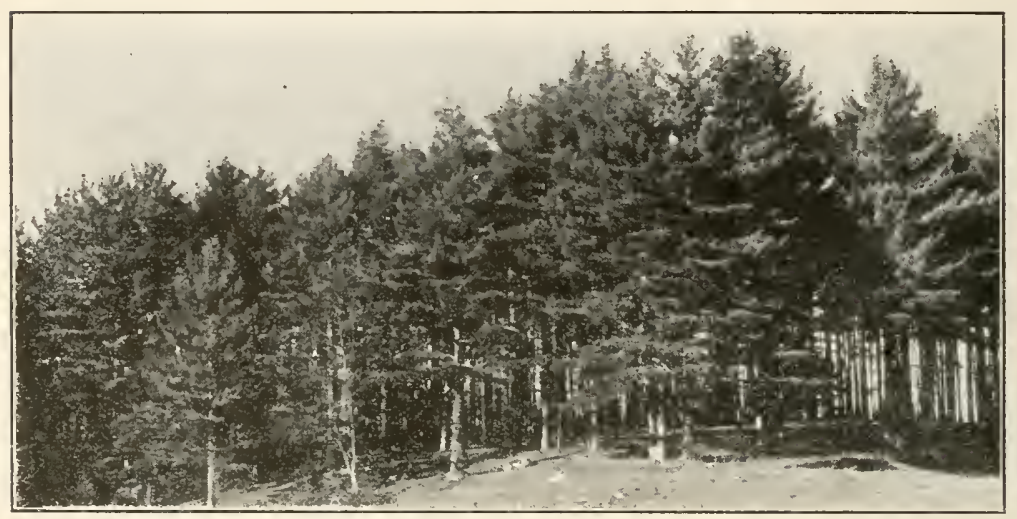

A thrifty White Pine Woodlot in New York, showing best use of unproductive hilltops and slopes.

The College of Forestry Will Identify Specimens of Trees, Shrubs and Woods

It may be that there are trees or shrubs growing about the school buildings or on the grounds about the homes of the boys and girls which are not known to them. It may be that certain woods are being used in manufacturing plants in the city or in repairing the school buildings or the hone buildings which are not known to the pupils. The College will be glad at all times to identify specimens of trees and shrubs and the woods, giving both the common and scientific names. If possible, with trees and shrubs send in small specimens of leaves, buds, and flowers or fruit if they can be obtained. A small piece of wood two or three inches long and an inch thick 
will be sufficient. It should be possible for the children of the school, through the aid which the College can give in identitication of trees to get acquainted with the trees of the entire community. Possibly the school may wish to assist in making a tree census in the community as well as aiding in the proper labeling of trees in the parks or about the public buildings. The College will supply tree and shrub labels of uniform size giving common and scientific names, and these at cost.

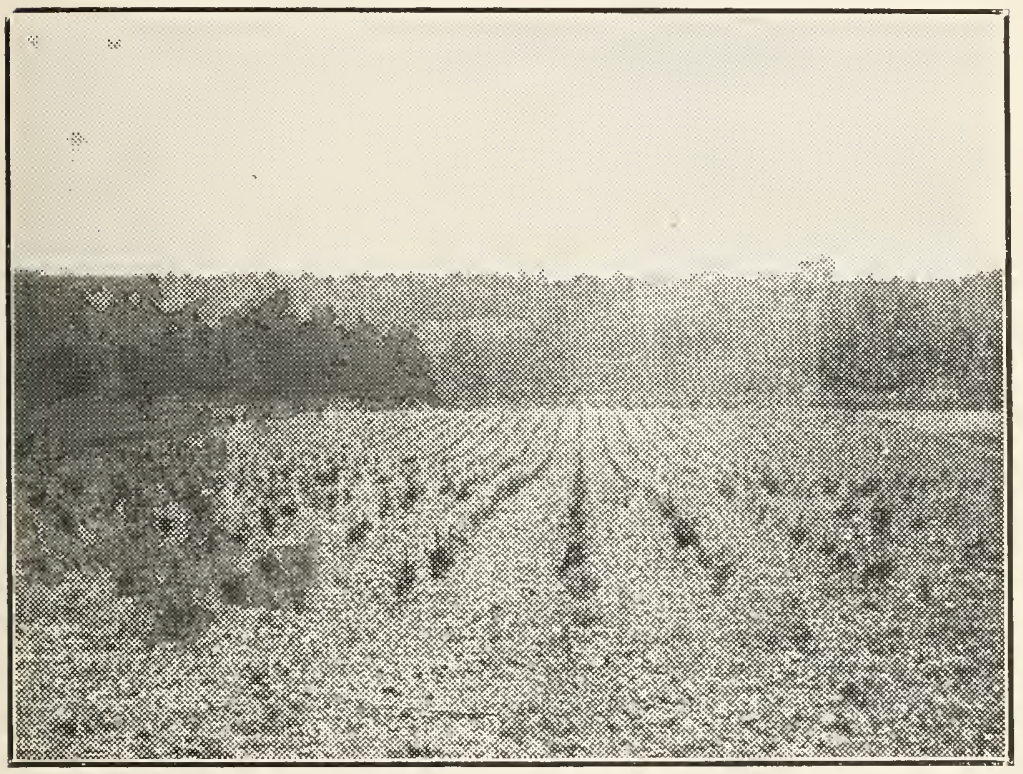

Spruce Plantation at State Forest Experiment Station, south of Syracuse 
THE NEW YORK STATE COLLEGE OF FORESTRY at

\section{SYRACUSE UNIVERSITY}

Designated and supported by the State as the Institution for educational work in Forestry in New York.

Offers at

SYRACUSE UNIVERSITY

\section{FOUR AND FIVE YEAR PROFESSIONAL COURSES,}

Leading to degrees of Bachelor of Science (B. S.), Master of Forestry (M. F.) and Doctor of Economics (D. Oec.).

At the State Ranger School on College Forest of 1,800 acres at IIanakena, in the Adirondacks, a one-year Ranger Course.

On Cranberry Lake, in the Western Adirondacks, the August Forest Camp, where anyone interested in the woods can get a montl of directed recreation along forestry lines.

Is a part of its State-wide educational work, the College offers to make plans for the protection and management of timberlands and woodlots and for the reforestation of cut-over and barren areas. Where the timberland, or woodlots, or barren areas are between 300 and 1,000 acres or over, and where there is a reasonable assurance that plans will be carried out, they will be made at no expense to the owner. Where there is less than the above amount, it will be necessary for owners to pay expenses of traveling and sustenance while the plan is being made. Owners of small tracts may combine and ly bringing the area to 300 or more acres, have plans made without cost.

The College invites correspondence at any time as to its educational work or regarding the protection and management of forests or woodlots, tree planting. forest insects and tree (iiseases, and timber treating. 